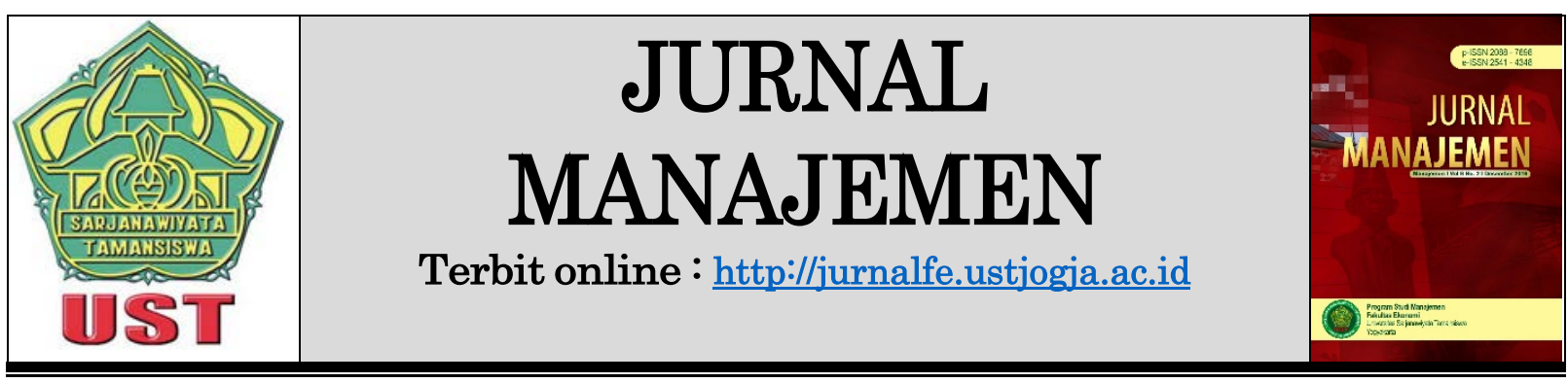

\title{
FAKTOR PENENTU SIKAP KONSUMEN UNTUK BERBELANJA DARING MELALUI MARKETPLACE
}

\section{Olivia Barcelona Nasution \\ STIE YKPN Yogyakarta}

Email: oliviabarcelona@stieykpn.ac.id

\begin{tabular}{lc}
\hline Informasi Naskah & Abstrak \\
\hline Diterima: & The purpose of this study is to examine the effect of \\
12 Maret & perceived benefit, perceived website quality and online trust \\
Revisi: & to attitude toward online shopping. This study used a \\
22 April & purposive sampling technique that was only consumers who \\
Terbit: & have made purchases online through a marketplace that can \\
28 Juni & be a respondent. \\
\hline Kata Kunci: & The number of respondents who filled out the research \\
Perceived Benefit, & questionnaire and which can be processed were 130 \\
Perceived Website & respondents. From testing multiple linear regression shows \\
Quality, Trust, & that perceived benefit, perceived website quality and online \\
Attitude Toward & trust have a significant positive effect on attitude toward \\
Online Shopping & online shopping, where attitude is one determinant of \\
& person's behavior.
\end{tabular}

\section{PENDAHULUAN}

Jumlah pengguna internet semakin meningkat setiap tahunnya, khususnya di Indonesia. Data pada Internet World Stats menunjukkan bahwa pengguna internet pada tahun 2017 sebanyak 143.260.000 dan Indonesia menduduki peringkat 5 besar negara dengan pengguna internet terbanyak di dunia. Meningkatnya jumlah pengguna internet juga turut meningkatkan jumlah konsumen yang melakukan pembelian secara daring. Data dari Statista menunjukkan jumlah pembeli daring di Indonesia pada tahun 2017 sebanyak 28,1 juta dan meningkat secara drastis pada tahun 2018 menjadi 31,6 juta orang.

Meningkatnya konsumen yang belanja secara daring disebabkan karena konsumen dengan lebih mudah mendapatkan barang yang diinginkan dan dibutuhkan tanpa harus pergi ke toko serta konsumen cenderung mendapatkan harga barang yang lebih murah ketika berbelanja secara daring. Hal ini karena penjualan secara daring menyingkatkan jalur distribusi barang sehingga harga yang dijual secara daring lebih murah (Nasution \& Nugroho, 2014). Selain itu, 
belanja daring menambah kemampuan pencarian dan pengumpulan informasi serta dengan transparansi dan kenyamanan yang tinggi (Al-Debei et al., 2015).

Wu (2003) menyatakan bahwa sikap merupakan hal yang paling penting dalam menentukan sukses atau gagalnya strategi pemasaran daring. Ada beberapa hal yang mempengaruhi pilihan pembelian konsumen yaitu motivasi, persepsi, pembelajaran dan kepercayaan serta sikap (Wu, 2003). Sikap konsumen didefinisikan sebagai tingkatan dimana seorang individu memiliki evaluasi yang menyenangkan atau tidak menyenangkan atau penilaian perilaku yang harus ditindaklanjuti. Sikap secara langsung mempengaruhi keputusan pembelian dan sikap juga berperan sebagai jembatan antara karakteristik latar belakang konsumen dan konsumsi yang memuaskan kebutuhannya (Wu, 2003).

Dari perspektif konsumen dan perbandingan dengan belanja secara konvensional, belanja daring memiliki keunggulan dan keuntungan (Liu et al., 2012). Pertama, belanja daring memungkinkan konsumen untuk membeli produk dan jasa dimana dan kapan pun mereka berada. Kedua, belanja daring membuat konsumen dapat menghemat uang, tenaga dan waktu ketika membeli, sehingga manfaat dari belanja daring akan berpengaruh signifikan pada sikap konsumen terhadap belanja daring (Al-Debei et al., 2015)

\section{KAJIAN PUSTAKA DAN HIPOTESIS}

Penelitian terdahulu menyebutkan bahwa desain dari website memengaruhi sikap konsumen terhadap belanja daring. Semakin tinggi kualitas website dari vendor daring, maka semakin positif pula sikap konsumen terhadap belanja daring (Zhou, 2011). Hasan (2016) menyatakan bahwa penting bagi vendor agar website menggunakan desain visual yang kaya dan menarik untuk menampilkan atribut produk sejelas dan setepat mungkin karena konsumen sangat bergantung pada kejelasan desain visual situs untuk menilai tampilan, nuansa, dan kualitas produk.

Selain kualitas website, kepercayaan konsumen daring menjadi salah satu faktor penting yang harus diperhatikan karena penjual daring yang anonim serta adanya asimetri informasi (Nasution, 2018). Meskipun jumlah pengguna internet meningkat, banyak pengguna tidak melakukan pembelian daring. Mereka enggan untuk membagikan informasi personal dan/atau informasi transaksional untuk pembayaran daring karena mereka tidak percaya dengan penjual daring (Ponte et al. , 2015). Padahal, peningkatan kepercayaan akan meningkatkan jumlah penjualan secara daring (Ray et al., 2011).

Dalam konteks penelitian, daring merupakan salah satu topik yang sedang banyak diteliti karena terkait dengan perkembangan internet. Toko daring dibedakan menjadi tiga, yaitu onlineshop yang menggunakan akun media sosial, e-commerce yang merupakan situs yang hanya menjual merek tertentu dan tidak berafiliasi dengan penjual lain (seperti zara, berrybenka, zalora, dan lain-lain), dan yang terakhir adalah marketplace yaitu situs yang menampung banyak penjual, sehingga produk yang dijual lebih beragam dan lebih lengkap dibandingkan jenis toko daring lainnya. Marketplace yang populer di Indonesia adalah Tokopedia, Shopee, Bukalapak, Elevenia, Lazada, Rakuten, dan lain-lain. Marketplace dipilih dalam penelitian ini karena produk yang dijual lebih beragam sehingga lebih sesuai dengan konteks pada 
penelitian ini.

Sikap adalah prediktor utama dari niat mengadopsi perilaku yang dijelaskan pada teori tindakan beralasan dan teori perilaku terencana (Ajzen, 1986; Ajzen, 1991). Sikap adalah kecenderungan yang dipelajari dalam berperilaku dengan cara menyenangkan atau tidak menyenangkan terhadap suatu objek tertentu (Schiffman \& Wisenblit, 2015). Dalam konteks perilaku konsumen, objek dapat berupa produk, merek, layanan, harga, paket, iklan, promosi, media, atau pengecer yang menjual produk, di antara banyak aspek lain dari konsumsi (Schiffman \& Wisenblit, 2015). Sikap merupakan faktor kunci dari anteseden niat pembelian konsumen secara daring (Chang et al., 2016). Sikap pada belanja daring dapat dijelaskan sebagai penilaian positif atau negatif individu dari perilaku yang signifikan dan terdiri dari keyakinan individu yang menonjol mengenai konsekuensi yang dirasakan dari melakukan suatu perilaku (Arora, 2017).

Konsumen melakukan pembelian secara daring karena kenyamanan dan kesenangan (Sarkar, 2011). Hal ini karena konsumen dapat melakukan pembelian di mana pun dan kapan pun waktu yang mereka inginkan untuk melakukan transaksi daring. Selain itu, belanja daring menawarkan alternatif produk yang lebih banyak (Chiu et al., 2014). Selain itu, manfaat yang dirasakan konsumen mengenai belanja daring adalah hal-hal yang terkait kenyamanan, penghematan waktu karena konsumen tidak perlu mengunjungi toko serta penghematan biaya (Al-Debei et al., 2015). Kemungkinan untuk menemukan produk yang diinginkan dan dibutuhkan akan lebih tinggi dibandingkan luring serta belanja daring memberikan pengalaman belanja yang efisien (Chiu et al., 2014). Penelitian terdahulu membuktikan bahwa manfaat yang dirasakan berpengaruh signifikan pada sikap konsumen terhadap belanja daring (Akroush \& Al-Debei, 2015; Al-Debei et al., 2015).

H1: Manfaat yang dirasakan berpengaruh positif pada sikap konsumen untuk berbelanja daring.

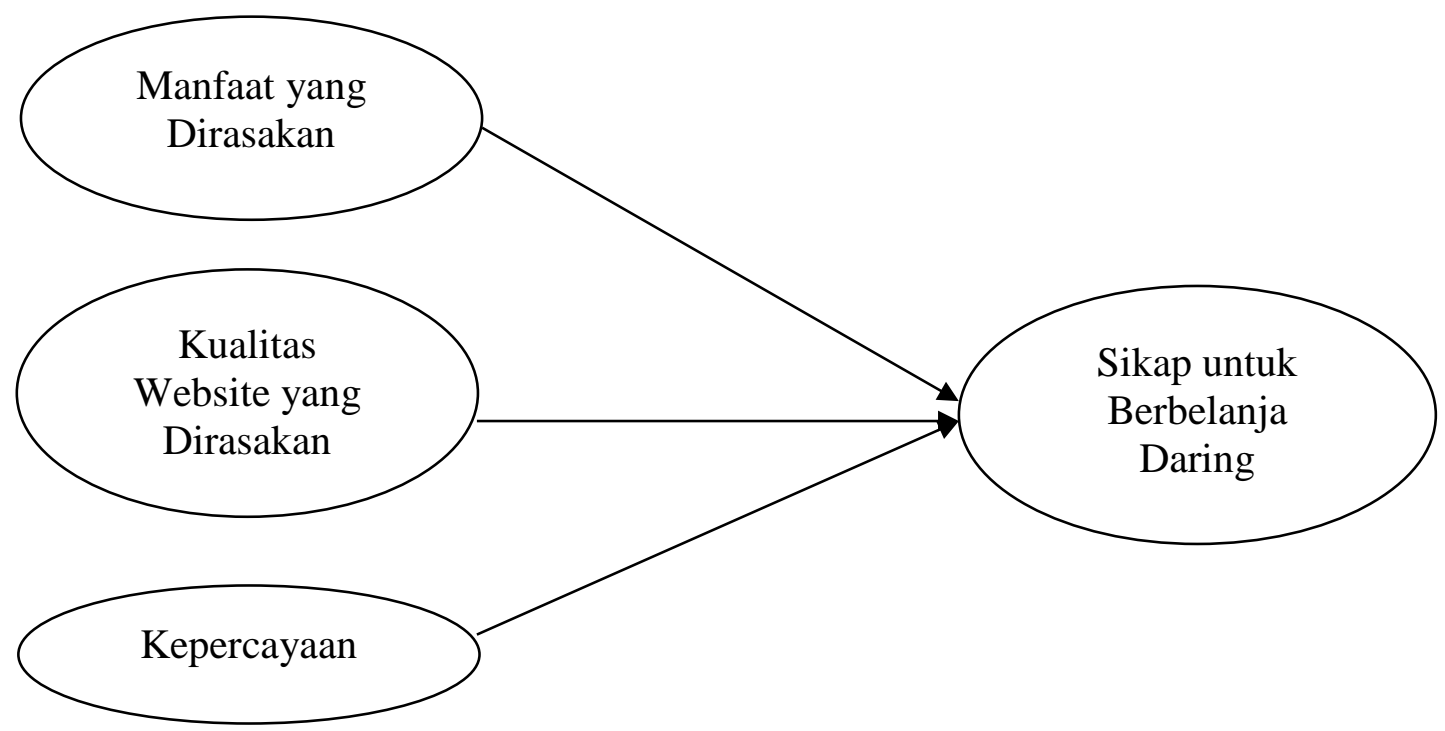

Gambar 1. Model Penelitian 
Kualitas website yang dirasakan mengacu pada kualitas dan kinerja secara keseluruhan dari website belanja daring. Al-Qeisi (2014) menyatakan bahwa kualitas website yang baik dapat meningkatkan minat konsumen untuk menggunakan kembali website yang sama. Kualitas website menjadi penting terutama pada vendor daring yang belum dikenal (Nilashi et al., 2016). Konsumen akan lebih memiliki sikap yang positif terhadap vendor dengan kualitas website yang bagus meskipun dengan reputasi yang tidak cukup baik dibandingkan dengan vendor dengan reputasi yang baik tetapi memiliki kualitas website yang buruk (Gregg \& Walczak, 2010). Penelitian Akroush dan Al-Debei (2015) membuktikan bahwa semakin baik kulaitas website vendor daring, maka akan menghasilkan sikap yang lebih positif dan menguntungkan terhadap belanja online.

H2: Kualitas website yang dirasakan berpengaruh positif pada sikap konsumen untuk berbelanja daring.

Kepercayaan adalah keyakinan konsumen bahwa penjual berperilaku secara etis (Pavlou dan Fygenson, 2006). Kepercayaan juga diartikan sebagai harapan dari satu pihak pada pihak yang lain dalam berperilaku (Hung, Cheng, \& Chen, 2012). Ketika melakukan transaksi secara daring, konsumen tidak mengetahui secara pasti dengan siapa mereka bertransaksi karena adanya asimetri informasi. Kepercayaan menjadi aspek yang paling penting dalam transaksi daring karena adanya keterbatasan konsumen dalam melakukan kontrol dan tidak ada jaminan bahwa vendor daring tidak akan melakukan perilaku oportunistik (Chiu et al., 2009). Beberapa penelitian terdahulu menunjukkan bahwa kepercayaan berpengaruh terhadap sikap dan niat konsumen untuk berperilaku (Nasution \& Nugroho, 2014; Akroush \& Al-Debei, 2015; Al-Debei et al., 2015).

H3: Kepercayaan daring berpengaruh positif pada sikap konsumen untuk berbelanja daring.

\section{METODE PENELITIAN}

Penelitian ini menggunakan metode purposive sampling, yaitu hanya konsumen dengan karateristik tertentu yang dapat menjadi responden pada penelitian ini. Responden dalam penelitian ini adalah konsumen yang pernah melakukan satu kali pembelian secara daring melalui marketplace dalam enam bulan terakhir karena dalam jangka waktu enam bulan, konsumen masih dapat digolongkan menjadi konsumen yang masih aktif (Pappas et al., 2014). Marketplace dipilih menjadi objek penelitian ini karena struktur websitenya yang lebih komplit dan terstruktur serta terdiri dari banyak penjual, sehingga lebih sesuai dengan konteks penelitian ini.

Penelitian ini menggunakan item-item kuesioner valid yang diadaptasi dari penelitian sebelumya dan peneliti melakukan validasi ulang. Semua konstruk model diukur dengan menggunakan skala Likert 5 poin yaitu dari 1 (sangat tidak setuju) hingga 5 (sangat setuju). Pengukuran variabel manfaat yang dirasakan menggunakan tiga item yang diadopsi dari penelitian Al-Debei 
et al. (2015). Variabel kualitas website yang dirasakan diukur menggunakan empat item dari penelitian Al-Debei et al. (2015). Variabel kepercayaan diukur dengan menggunakan tiga item dari penelitian Akroush dan Al-Debei (2015). Untuk variabel sikap terhadap belanja daring diukur dengan menggunakan tiga item dari penelitian Akroush dan Al-Debei (2015). Kuesioner penelitian ini disebarkan dengan menggunakan tautan Google doc. Penyebaran kuesioner dilakukan selama 2 minggu. Jumlah responden dalam penelitian ini adalah 130 orang.

Tabel 1. Profil Demografi Responden

\begin{tabular}{cccc}
\hline Demografi & Kategori & Frekuensi & \% \\
\hline Jenis & Laki-laki & 63 & 48,5 \\
Kelamin & & & \\
& Perempuan & 67 & 51,5 \\
Umur & $0-18$ & 9 & 6,9 \\
& $19-24$ & 82 & 63,1 \\
& $25-34$ & 31 & 23,8 \\
& $35-44$ & 6 & 4,6 \\
Pendidikan & $\geq 45$ & 2 & 1,5 \\
& SMA & 56 & 43,1 \\
& Diploma & 6 & 4,6 \\
& S1 & 55 & 42,3 \\
& S2 & 13 & 10,0 \\
\hline
\end{tabular}

Sumber: Data Diolah (2018)

Tabel 1 menunjukkan bahwa mayoritas responden dalam penelitian ini adalah berjenis kelamin perempuan (51,5 persen) dibandingkan laki-laki $(48,5$ persen). Untuk usia, mayoritas responden berumur 19 sampai 24 tahun (63,1 persen). Pendidikan terakhir mayoritas responden dalam penelitian ini adalah sarjana $(42,3)$.

\section{HASIL DAN PEMBAHASAN}

Data yang diuji dalam penelitian ini adalah jawaban kuesioner yang disebarkan pada responsen. Analisis data yang digunakan adalah analisis regresi berganda dan dilakukan dengan menggunakan SPSS 23. Untuk tahapan awal, peneliti melakukan pengujian validitas dan reliabilitas instrumen. Uji reliabilitas menggunakan Cronbach's alpha dengan nilai batas minimal 0,6 untuk setiap variabel. Pengujian validitas dilakukan dengan validitas konvergen menggunakan analisis faktor konfirmatori dengan batas loading factor minimal 0,5.

Tabel 2. Statistik Deskriptif, Validitas dan Reliabilitas

\begin{tabular}{lccccc}
\hline \multicolumn{1}{c}{ Variabel } & Rata-rata & $\begin{array}{c}\text { Standar } \\
\text { Deviasi }\end{array}$ & Item & $\begin{array}{c}\text { Factor } \\
\text { Loadings }\end{array}$ & $\begin{array}{c}\text { Cronbach's } \\
\text { Alpha }\end{array}$ \\
\hline Manfaat yang & \multirow{2}{*}{3,7923} & 0,61248 & MD1 & 0,740 & 0,689 \\
Dirasakan & & & MD2 & 0,854 & 0,689
\end{tabular}




\begin{tabular}{|c|c|c|c|c|c|}
\hline \multirow{4}{*}{$\begin{array}{l}\text { Kualitas Website yang } \\
\text { Dirasakan }\end{array}$} & \multirow{4}{*}{3,9308} & \multirow{4}{*}{0,61238} & MD3 & 0,560 & \multirow{4}{*}{0,874} \\
\hline & & & KW1 & 0,791 & \\
\hline & & & KW2 & 0,797 & \\
\hline & & & KW3 & 0,802 & \\
\hline \multirow{4}{*}{ Kepercayaan } & \multirow{4}{*}{3,9128} & \multirow{4}{*}{0,7267} & KW4 & 0,793 & \multirow{4}{*}{0,824} \\
\hline & & & $\mathrm{K} 1$ & 0,554 & \\
\hline & & & $\mathrm{K} 2$ & 0,808 & \\
\hline & & & K3 & 0,728 & \\
\hline \multirow{3}{*}{$\begin{array}{l}\text { Sikap untuk } \\
\text { Berbelanja Daring }\end{array}$} & \multirow{3}{*}{3,7821} & \multirow{3}{*}{0,63043} & SBD1 & 0,810 & \multirow{3}{*}{0,729} \\
\hline & & & SBD2 & 0,676 & \\
\hline & & & SBD3 & 0,574 & \\
\hline
\end{tabular}

Sumber: Data Diolah (2018)

Penelitian ini menguji pengaruh manfaat yang dirasakan, kualitas website yang dirasakan dan kepercayaan daring pada sikap untuk berbelanja daring. Tabel 3 menunjukkan hasil pengujian regresi berganda untuk tiga hipotesis yang diuji. Hasilnya menunjukkan bahwa manfaat yang dirasakan (B $=0,175)$, kualitas website yang dirasakan $(B=0,367)$ dan kepercayaan daring $(B=0,291)$ berpengaruh positif signifikan pada sikap untuk berbelanja daring $(\mathrm{p}<0,05)$.

Hasil penelitian ini sejalan dengan beberapa penelitian terdahulu (Akroush \& Al-Debei, 2015; Al-Debei et al., 2015). Proses jual dan beli secara daring memiliki resiko yang sangat besar, akan tetapi hasil penelitian menunjukkan bahwa manfaat yang dirasakan konsumen lebih besar dibanding resiko yang dipersepsikan. Manfaat belanja daring yang dirasakan konsumen yaitu adanya penghematan waktu karena kosumen tidak perlu mengunjungi toko fisik. Selain itu, konsumen juga mendapatkan produk yang lebih murah dibanding toko luring karena tidak adanya biaya untuk gedung toko sehingga produk yang dijual daring biasanya lebih murah. Hal yang dapat dilakukan penjual daring untuk menciptakan perilaku pembelian kembali adalah dengan mewujudkan manfaat nyata belanja daring yang diharapkan konsumen serta mengurangi resiko yang dipersepsikan konsumen.

Tabel 3. Hasil Pengujian Regresi

\begin{tabular}{|c|c|c|c|}
\hline Variabel & $B$ & $\begin{array}{l}\mathrm{t}^{-} \\
\text {value }\end{array}$ & Sig. \\
\hline $\begin{array}{ll}\text { Manfaat } & \text { yang } \\
\text { Dirasakan } & \end{array}$ & 0,175 & 3,268 & 0,001 \\
\hline $\begin{array}{l}\text { Kualitas Website yang } \\
\text { Dirasakan }\end{array}$ & 0,367 & 2,347 & 0,020 \\
\hline Kepercayaan & 0,291 & 4,461 & 0,000 \\
\hline Ajusted $R^{2}$ & 0,467 & & \\
\hline $\mathrm{F}$ & 38,627 & & \\
\hline Sig. & 0,000 & & \\
\hline
\end{tabular}

Sumber: Data Diolah (2018) 
Kualitas website juga turut menjadi perhatian penting bagi penjual daring karena fungsionalitas, kemudahan penggunaan, keamanan dan privasi dapat memainkan peran besar dalam membentuk sikap positif konsumen pada belanja daring (Akroush \& Al-Debei, 2015). Ketika kualitas website dipersepsikan baik oleh konsumen, artinya penjual memang dianggap mempermudah konsumen untuk melaksanakan transaksi daring. Tampilan website yang baik akan menciptakan persepsi profesionalitas suatu vendor di benak konsumen.

Penjual yang anonim dan adanya asimetri informasi serta ketakutan pada oportunisme membuat konsumen ragu untuk melakukan pembelian secara daring. Jika penjual daring menciptakan kepercayaan pada pembelian awal konsumen maka akan meningkatkan niat untuk melakukan pembelian kembali yang diinisiasi oleh sikap positif pada belanja daring (Nasution \& Nugroho, 2014). Kepercayaan adalah kunci dalam transaksi secara daring. Konsumen yang melakukan pembelian daring pada suatu vendor artinya telah memiliki kepercayaan awal. Jika vendor daring tersebut melampaui ekspektasi konsumen, maka kepercayaan konsumen akan terus meningkat. Seiring dengan meningkatnya kepercayaan konsumen, maka sikap konsumen juga akan semakin meningkat dan sikap positif yang dimiliki konsumen akan berubah menjadi perilaku, baik itu pembelian kembali maupun memberikan rekomendasi positif atau getok tular positif (positive WOM).

\section{PENUTUP}

Berdasarkan hasil pengujian dalam penelitian ini, maka dapat disimpulkan bahwa manfaat yang dirasakan, kualitas website yang dirasakan dan kepercayaan daring berpengaruh positif signifikan pada sikap terhadap belanja daring. Oleh karena itu, penting bagi praktisi daring untuk memperhatikan segala aspek yang berkontribusi pada peningkatan sikap positif konsumen pada belanja daring dimana sikap merupakan penentu terbesar seseorang dalam berperilaku.

Penelitian ini masih memiliki keterbatasan. Penelitian selanjutnya diharapkan dapat menguji variabel lainnya yang diduga menjadi pemicu munculnya sikap terhadap belanja daring konsumen. Selain itu, penelitian yang akan datang diharapkan menguji sikap konsumen pada penjual yang memiliki website independen karena penelitian ini menggunakan objek marketplace dimana website yang termasuk dalam marketplace sudah lebih terstandar.

\section{REFERENSI}

Ajzen, I. (1986). Prediction of Goal-Directed Behavior : Attitudes , Intentions , and Perceived Behavioral Control, 474, 453-474.

Akroush, M. N., \& Al-Debei, M. M. (2015). An integrated model of factors affecting consumer attitudes towards online shopping. Business Process Management Journal, 21(6), 1353-1376. https://doi.org/10.1108/BPMJ-022015-0022 
Al-Debei, M. M., Akroush, M. N., \& Ashouri, M. I. (2015). Consumer attitudes towards online shopping: The effects of trust, perceived benefits, and perceived web quality. Internet Research, 25(5), 707-733. https://doi.org/10.1108/IntR-05-2014-0146

Al-Qeisi, K., Dennis, C., Alamanos, E., \& Jayawardhena, C. (2014). Website design quality and usage behavior: Unified Theory of Acceptance and Use of Technology. Journal of Business Research, 67(11), 2282-2290.

Bonsón Ponte, E., Carvajal-Trujillo, E., \& Escobar-Rodríguez, T. (2015). Influence of trust and perceived value on the intention to purchase travel online: Integrating the effects of assurance on trust antecedents. Tourism Management, 47, 286-302. https://doi.org/10.1016/j.tourman.2014.10.009

Chang, W., Franke, G. R., \& Lee, N. (2016). Comparing re fl ective and formative measures: New insights from relevant simulations 论, 69, 3177-3185. https://doi.org/10.1016/j.jbusres.2015.12.006

Chen, Y.T. \& Chou, T.Y. (2012), "Exploring the continuance intentions of consumers for B2C online shopping: perspectives of fairness and trust", Online Information Review, Vol. 36 No. 1, pp. 104-125.

Chiu, C., Lin, H., Sun, S., \& Hsu, M. (2009). Understanding customers ' loyalty intentions towards online shopping: an integration of technology acceptance model and fairness theory, 28(4), 347-360. https://doi.org/10.1080/01449290801892492

Chiu, C. M., Wang, E. T. G., Fang, Y. H., \& Huang, H. Y. (2014). Understanding customers' repeat purchase intentions in B2C e-commerce: The roles of utilitarian value, hedonic value and perceived risk. Information Systems Journal, 24(1), 85-114. https://doi.org/10.1111/j.1365-2575.2012.00407.x

Frekuensi, P., Studi, B., Webmall, P., \& Nasution, O. B. (2018). Peran frekuensi belanja (studi pada webmall), 6(2), 111-122.

Gregg, D. G., \& Walczak, S. (2010). The relationship between website quality , trust and price premiums at online auctions, 1-25. https://doi.org/10.1007/s10660-010-9044-2

Hasan, B. (2016). Perceived irritation in online shopping: The impact of website design characteristics. Computers in Human Behavior, 54, 224-230. https://doi.org/10.1016/j.chb.2015.07.056

Hung, S., Cheng, M., \& Chen, P. (2012). Reexamining the Factors for Trust in Cultivating Online Customer Repurchase Intentions: The Moderating Effect of Perceived Waiting, 666-677. https://doi.org/10.1080/10447318.2011.654201

Liu, M. T., \& Wong, I. A. (2012). Exploring the relationship among affective loyalty, perceived benefits, attitude, and intention to use co-branded products. https://doi.org/10.1108/13555851211259025

Nasution, O. B., \& Nugroho, S. S. (2014). Does the previous consumer transaction experience strengthen repurchase intention on webmall?

Nilashi, M., Jannach, D., Ibrahim, O. bin, Esfahani, M. D., \& Ahmadi, H. (2016). Recommendation quality, transparency, and website quality for trustbuilding in recommendation agents. Electronic Commerce Research and Applications, 19, 70-84. https://doi.org/10.1016/j.elerap.2016.09.003

O. Pappas, I., G. Pateli, A., N. Giannakos, M., \& Chrissikopoulos, V. (2014). Moderating effects of online shopping experience on customer satisfaction 
and repurchase intentions. International Journal of Retail \& Distribution Management, 42(3), 187-204. https://doi.org/10.1108/IJRDM-03-2012-0034

Pavlou, P.A., Liang, H. and Xue, Y. (2007), "Understanding and mitigating uncertainty in online exchange relationships: a principal-agent perspective", MIS Quarterly, Vol. 31 No. 1, pp. 105-36.

Ray, S., Ow, T., \& Kim, S. S. (2011). Security Assurance: How Online Service Providers Can Influence Security Control Perceptions and Gain Trust. Decision Sciences, 42(2), 391-412. https://doi.org/10.1111/j.15405915.2011.00316.x

Sarkar, A. (2011). Impact of Utilitarian and Hedonic Shopping Values on Individual' s Perceived Benefits and Risks in Online Shopping. International Management Review, 7(1), 58-95. https://doi.org/10.1016/j.chb.2006.05.006

Schiffman, L. G., \& Wisenbilt, J. L. (2015). Consumer Behavior. London: Pearson

Transfer, T. (2017). The impact of trust on online shopping attitude among women shoppers in India Nupur Arora * and Manmohan Rahul, 15(3), 360381.

Wu, S. I. (2003). The relationship between consumer characteristics and attitude toward online shopping. Marketing Intelligence \& Planning, 21(1), 37-44. https://doi.org/10.1108/02634500310458135

Zhou, T. (2011). Examining the critical success factors of mobile website adoption, (71001030). https://doi.org/10.1108/14684521111161972 